\title{
Relationship between vocal symptoms in college students and their possible causes
}

\author{
Léslie Piccolotto Ferreira', Juliana Ranzani Guerra², Camila Miranda Loiolaª, Ana Carolina de Assis Moura Ghirardi. \\ 1) $\mathrm{PhD}$ in Human Communication Disorders at Federal University of São Paulo - Paulista School of Medicine (UNIFESP-EPM). Full Professor of the Department of the \\ Phonoaudiology Clinic of the College of Human and Health Sciences of the Pontifical Catholic University of São Paulo, PUC-SP; Professor and Coordinator of the \\ PEPG in Speech-Language Pathology. \\ 2) Master's Degree in Speech-Language Pathology from the Graduate Studies Program in Speech-Language Pathology at PUC-SP. Speech-Language Pathologist. \\ 3) Master's Degree in Speech-Language Pathology from the Graduate Studies Program in Speech-Language Pathology at PUC-SP. Speech-Language Pathologist; PhD \\ student at the Graduate Studies Program in Speech-Language Pathology at PUC-SP. \\ Institution: Pontifícia Universidade Católica de São Paulo-PUC-SP \\ São Paulo / SP - Brazil. \\ Mailing address: Leslie Piccolotto Ferreira - Rua Jesuíno Bandeira, 73 - Vila Romana - São Paulo / SP - Brazil - Zip code: $05048-080$ - E-mail: milaloiola@ yahoo.com.br \\ Article received in June 28, 2010. Article approved in March 18, 2012.
}

\section{SUMMARY}

Introduction: Studies to understand the vocal profile of a population are important to plan collective health measures. The prevalence of vocal symptoms can be indicative of vocal disorder and must be investigated to support measures to prevent vocal diseases.

Aim: To characterize vocal symptoms in college students and their possible causes, and to analyze the association between hoarseness, vocal fatigue, phlegm, and burning in the throat with the possible causes mentioned.

Method: Prospective study of 517 students who answered a questionnaire about their general heath and vocal symptoms and causes. We used the study of proportions, measures of central tendency, and a chi-square test to associate the presence of symptoms and possible causes.

Results: Symptoms most often mentioned: dry mouth (21\%), dry throat (18.2\%), phlegm (17.9\%). Causes most often cited: high respiratory disease (39\%), intense voice use (24\%), smoking (24\%). Hoarseness was associated with heavy use of voice and high respiratory disease; vocal fatigue with intense voice use, stress, and digestive problems; burning in the throat with intensive voice use, high respiratory disease, and pollution; phlegm with smoking, and upper respiratory and digestive problems.

Conclusion: Not only do aspects of health and the voice interfere with its production, the external environment and habits influence the vocal symptoms of this population as well.

Keywords: epidemiology, voice, voice disorders, speech, language and hearing sciences.

\section{INTRODUCTION}

Even though the speech-language pathologist (SLP), with voice professionals, has developed more effective proposals for health promotion from the end of the 20th century onward, he remains focused on the rehabilitation of a small group of individuals, setting aside issues pertaining to a more collective setting, health promotion, and prevention of voice disorders. Therefore, this professional is distanced from the epidemiological principles that, especially in this situation, should be his main setting for work and study. Population studies that aim to determine the vocal profile and general health states of a population are still recent in the field of speech-language pathology. These studies subsidize prevention measures for voice disorders, and are therefore extremely important in order to plan collective health measures. For this reason, it is necessary to conduct epidemiological studies in this field to structure speech-language pathology practices in possible health measures.
According to a previous study (1), the prevalence of vocal symptoms should be perceived as an indication of a suspected voice disorder. Among possible vocal symptoms, the ones most commonly observed in dysphonic individuals are hoarseness (2) and vocal fatigue (3), and investigations should be carried out if these occur in isolation. Sore throat and phlegm are also mentioned in the literature, as follows.

An epidemiological study was conducted in Finland (4). In this study, 226 education students completed a questionnaire to determine the occurrence of vocal problems in this population. The findings revealed that $34 \%$ of respondents reported vocal problems. The symptoms most commonly mentioned were vocal fatigue, hoarseness, and sore throat.

In Brazil, a population of 451 individuals was observed during the National Voice Week Campaign of 1999 (5). The data showed that $58 \%$ of the population mentioned hoarseness, and that $24 \%$ of individuals mentioned a sore throat. 
Otorhinolaryngological symptoms were investigated in a study of 293 schoolchildren aged between 7 and 14 years (6), and the findings revealed that $9 \%$ of the children mentioned hoarseness, albeit this being less frequent than that in previous studies.

Therefore, it was observed that vocal symptoms are present in different populations independently of age group or occupation. Thus, the aim of the present study was to characterize the presence of vocal symptoms and their possible causes in a group of college students and to analyze the association of some of these symptoms (hoarseness, vocal fatigue, sore throat, and phlegm) to the possible causes reported by the students.

\section{Method}

The Research Ethics Committee of the institution approved this epidemiological cross-sectional study under approval number 0045/2004, and all subjects signed an informed, free consent form.

The study was conducted at a private university in the city of São Paulo. This environment was chosen as it presented easy access to the studied population, and all the individuals were in the same geographical area, had the same level of schooling, and theoretically, at least similar social, economic, and cultural levels. All freshman students in 18 social science courses from the morning, afternoon, night, and full sessions were invited to participate as volunteers in this study.

The age range for participants was set between 17 and 45 years of age. The lower limit was considered to exclude vocal interferences of voice changing, and the upper limit was defined thusly because of the several laryngeal alterations that may appear after this age due to the effects of hormones, particularly in women (7).

The instrument used for data collection was an adapted questionnaire (8) composed of the following questions:

1. Sample characterization: Date of birth, age, course, period, year of starting college, and date of questionnaire completion;

2. General health aspects: Self-perception of health compared to others of the same age, current medical treatments, use of medication, and smoking;

3. Vocal aspects: Hoarseness, cough with secretion, lack of air, lower-pitched voice, higher-pitched voice, high/ low pitch variations in voice, weak voice, vocal strain/ fatigue, voice loss, dry cough, phlegm, sore throat, dry throat, dry mouth, difficulty swallowing, voice breaks, strain when speaking, burning sensation when speaking — and possible causes for these symptomsintense vocal use, respiratory infections, stress, smoking, flu, allergies, medications, digestive issues, among others.

The answers regarding respiratory infection, flu, and allergy were grouped into one category (upper airway infections) as the studied population might have found it challenging to differentiate these manifestations.

Before its definitive submission for completion, 13 evaluators, who were professionals in different areas, analyzed the questionnaire, and then a pilot study was conducted to make the necessary adjustments to the instrument. Students from 2 different majors were chosen for this purpose: social sciences, as they were in 2 different classrooms in the same period/semester, and speechlanguage pathology, as it was assumed that the students of this major had at least partial knowledge of the questions in the instrument. It should be noted that the students who participated in this phase of the investigation and their questionnaire answers were excluded from the final result analysis in the study.

For the purpose of data collection, the main researcher visited each classroom and asked the lecturer for permission to administer the questionnaire. After obtaining permission, 571 students volunteered to participate in the study, and received information regarding the completion of the questionnaire. At the end of this procedure, they each read and signed the informed, free consent form, which explained the aim and provided information on the study. This was accomplished as a final step, as prior knowledge about the specific study aims could have influenced their responses.

After collecting the completed questionnaires, the data were typed twice to eliminate inadvertent mistakes. The statistical software used for data analysis was SPSS version 10.0 for Windows, and all analyses considered a descriptive level ( $\mathrm{p}$ value) lower than or equal to $5 \%$.

The study population was characterized using proportions and measures of central tendency. A chisquare test was used to verify the existence of statistical association between the presence of each dependent variable reported by the studied population (hoarseness, vocal fatigue, sore throat, and phlegm) with their possible causes.

\section{RESULTS}

Of the 571 participating college students, 59.9\% were women, with ages varying between 17.8 and 39.9 years $($ mean $=21.25$ years). 
Regarding self-perception of their general health states, most subjects classified their state as good (54.1\%) or excellent (29.9\%). As far as the use of medication went, $25.2 \%$ reported using some kind of medication, and this number was higher than those who reported being in some kind of medical treatment (17\%). Smoking was reported by $30.5 \%$ of the studied population (Table 1 ).

Regarding the occurrence of symptoms related to voice disorders, the symptoms most frequently reported by the students were dry mouth (21\%), dry throat (18.2\%), phlegm (17.9\%), shortness of breath (15.2\%), and hoarseness (15.9\%). When declaring the possible causes for the occurrence of these symptoms, those most frequently mentioned were upper respiratory affections (39\%), intense vocal use (24\%), smoking (24\%), and stress (21.2\%) (Table 2).

In relation to the number of symptoms reported by each of the participating subjects, it was verified that from the total, $38.4 \%$ reported 1 or 2 symptoms related to voice disorders, while $27.6 \%$ mentioned more than 2 symptoms. Some of the subjects (34\%) reported that they did not perceive any vocal symptoms.

Regarding the number of different causes reported by each of the participating subjects, more than half (57.6\%) mentioned only one possible cause for the reported vocal symptom.

Regarding the analysis results of the association between the presence of hoarseness, vocal fatigue, sore throat, and phlegm and their possible causes (intense vocal use, smoking, upper airway affections, use of medication, digestive issues, and pollution) (Table 3), there was statistical significance between the presence of hoarseness and intense vocal use $(p<0.001)$ and upper respiratory affections ( $\mathrm{p}<0.001)$. There was no significant association between the presence of hoarseness and the following variables: stress $(p=0.387)$, smoking ( $p=0.663)$, use of medication ( $p=0.155)$, digestive issues $(p=0.309)$, and pollution $(\mathrm{p}=0.532)$.

Regarding vocal fatigue, statistical significance was verified between the presence of this symptom and intense vocal use $(p=0.001)$, stress $(p<0.001)$, and digestive issues $(p=0.002)$. There was no significant association between the presence of vocal fatigue and the following variables: smoking ( $\mathrm{p}=0.523)$, upper respiratory affections ( $p=0.614)$, use of medication ( $p=0.052)$, and pollution $(\mathrm{p}=0.806)$.

As far as the presence of sore throat went, there was a significant statistical association between the presence of this symptom and intense vocal use $(\mathrm{p}=$
Table I. Numerical ( $\mathrm{n}$ ) and percentage (\%) distribution of individuals according to sex, age, self-perception of general health state, medical treatment, use of medication, and smoking.

\begin{tabular}{lccc}
\hline Variable & Category & $\mathrm{n}$ & $\%$ \\
\hline Sex & Female & 342 & 59.9 \\
& Male & 229 & 40.1 \\
Age & $<21$ & 397 & 69.5 \\
& $>21$ & 174 & 30.5 \\
General healthin & Excellent & 171 & 29.9 \\
relationto others & Good & 309 & 54.1 \\
& Fair & 79 & 13.8 \\
& Poor & 12 & 2.2 \\
Medicaltreatment & Yes & 97 & 17.0 \\
& No & 474 & 83.0 \\
Use of medication & Yes & 144 & 25.2 \\
& No & 427 & 74.8 \\
Smoking & Yes & 174 & 30.5 \\
& No & 397 & 69.5 \\
\hline Total & & $57 \mid$ & 100.0 \\
\hline
\end{tabular}

Table 2. Numerical (n) and percentage (\%) distribution of individuals according to reported vocal symptoms and their possible causes.

\begin{tabular}{|c|c|c|c|}
\hline Variable & Category & $n$ & $\%^{a}$ \\
\hline \multirow[t]{19}{*}{ Vocal symptoms } & Drymouth & 120 & 21.0 \\
\hline & Drythroat & 104 & 18.2 \\
\hline & Phlegm/secretion ${ }^{b}$ & 102 & 17.9 \\
\hline & Shortness of breath & 87 & 15.2 \\
\hline & Hoarseness $^{b}$ & 85 & 14.9 \\
\hline & Cough withsecretion & 85 & 14.9 \\
\hline & Drycough & 70 & 12.3 \\
\hline & Vocalfatigue $^{b}$ & 67 & 11.7 \\
\hline & Sorethroat ${ }^{b}$ & 61 & 10.7 \\
\hline & Lower-pitchedvoice & 49 & 8.6 \\
\hline & Voice breaking & 44 & 7.7 \\
\hline & High/low-pitch varying voice & 34 & 6.0 \\
\hline & Voice loss & 31 & 5.4 \\
\hline & Vocalstrain & 22 & 3.9 \\
\hline & Weakvoice & 24 & 4.2 \\
\hline & Difficulty swallowing & 24 & 4.2 \\
\hline & Strongvoice & 13 & 2.3 \\
\hline & Pain when speaking & 9 & 1.6 \\
\hline & Higher-pitchedvoice & 4 & 0.7 \\
\hline \multirow[t]{10}{*}{ Causes of symptoms } & Upper respiratory affections & 219 & 39.0 \\
\hline & Intense vocal use & 135 & 24.0 \\
\hline & Smoking & 135 & 24.0 \\
\hline & Stress & 119 & 21.2 \\
\hline & Digestive issues & 25 & 4.4 \\
\hline & Pollution & 20 & 3.5 \\
\hline & Use of medication & 14 & 2.5 \\
\hline & Do not know & 107 & 19.0 \\
\hline & Otherreason & 82 & 14.7 \\
\hline & Noreason & 30 & 5.3 \\
\hline
\end{tabular}

\% In relation to the total sample $(\mathrm{N}=57 \mathrm{I})$.

${ }^{b}$ Dependent variables in the presentstudy. 
Table 3. Numerical ( $\mathrm{n}$ ) and percentage (\%) distribution of individuals according to the presence of hoarseness, vocal fatigue, sore throat, and phlegm, and the causes attributed to these symptoms.

\begin{tabular}{|c|c|c|c|c|c|c|c|c|c|c|c|c|c|c|}
\hline \multirow[t]{2}{*}{ Variable } & \multirow[t]{2}{*}{ Category } & \multirow[t]{2}{*}{ Ntotal } & \multicolumn{3}{|c|}{ Hoarseness } & \multicolumn{3}{|c|}{ Vocal fatigue } & \multicolumn{2}{|c|}{ Sore throat } & \multicolumn{4}{|l|}{ Phlegm } \\
\hline & & & $\begin{array}{c}\text { No } \\
n \\
(\%)\end{array}$ & $\begin{array}{c}\text { Yes } \\
n \\
(\%)\end{array}$ & $\mathrm{p}$ & $\begin{array}{c}\text { No } \\
\text { n } \\
(\%)\end{array}$ & $\begin{array}{c}\text { Yes } \\
n \\
(\%)\end{array}$ & $p$ & $\begin{array}{c}\text { No } \\
\text { n } \\
(\%)\end{array}$ & $\begin{array}{c}\text { Yes } \\
n \\
(\%)\end{array}$ & p & $\begin{array}{c}\text { No } \\
n \\
(\%)\end{array}$ & $\begin{array}{c}\text { Yes } \\
\mathrm{n}\end{array}$ & $p$ \\
\hline Intense vocal use & $\begin{array}{l}\text { Yes } \\
\text { No }\end{array}$ & $\begin{array}{l}135 \\
427\end{array}$ & $\begin{array}{c}90 \\
(16,0) \\
387 \\
(68,9)\end{array}$ & $\begin{array}{c}45 \\
(8,0) \\
40 \\
(7,1)\end{array}$ & $<0,001^{a}$ & $\begin{array}{c}108 \\
(19,2) \\
387 \\
(68,9)\end{array}$ & $\begin{array}{c}27 \\
(4,8) \\
40 \\
(7,1)\end{array}$ & $0,001^{a}$ & $\begin{array}{c}114 \\
(20,3) \\
387 \\
(68,9)\end{array}$ & $\begin{array}{c}21 \\
(3,7) \\
40 \\
(7,1)\end{array}$ & $0,044^{a}$ & $\begin{array}{c}112 \\
(19,9) \\
348 \\
(61,9)\end{array}$ & $\begin{array}{c}23 \\
(4,1) \\
79 \\
(14,1)\end{array}$ & 0,7 \\
\hline Stress & $\begin{array}{l}\text { Yes } \\
\text { No }\end{array}$ & $\begin{array}{l}119 \\
443\end{array}$ & $\begin{array}{c}98 \\
(17,4) \\
379 \\
(67,4)\end{array}$ & $\begin{array}{c}21 \\
(3,8) \\
64 \\
(11,4)\end{array}$ & 0,387 & $\begin{array}{c}83 \\
(14,8) \\
412 \\
(73,3)\end{array}$ & $\begin{array}{c}36 \\
(6,4) \\
31 \\
(5,5)\end{array}$ & $<0,001^{a}$ & $\begin{array}{c}10 \mid \\
(18,0) \\
400 \\
(71,2)\end{array}$ & $\begin{array}{c}18 \\
(3,2) \\
43 \\
(7,6)\end{array}$ & 0,092 & $\begin{array}{c}92 \\
(16,4) \\
368 \\
(65,5)\end{array}$ & $\begin{array}{c}27 \\
(4,8) \\
75 \\
(13,3)\end{array}$ & 0,148 \\
\hline Smoking & $\begin{array}{l}\text { Yes } \\
\text { No }\end{array}$ & $\begin{array}{l}135 \\
427\end{array}$ & $\begin{array}{c}113 \\
(20,1) \\
364 \\
(64,8)\end{array}$ & $\begin{array}{c}22 \\
(3,9) \\
63 \\
(11,2)\end{array}$ & 0,663 & $\begin{array}{c}12 \mid \\
(21,5) \\
374 \\
(66,5)\end{array}$ & $\begin{array}{c}14 \\
(2,5) \\
53 \\
(9,5)\end{array}$ & 0,523 & $\begin{array}{c}126 \\
(22,4) \\
375 \\
(66,7)\end{array}$ & $\begin{array}{c}9 \\
(1,6) \\
52 \\
(9,3)\end{array}$ & 0,073 & $\begin{array}{c}89 \\
(15,8) \\
37 \mid \\
(66,0)\end{array}$ & $\begin{array}{c}46 \\
(8,2) \\
56 \\
(10,0)\end{array}$ & $<0,001^{a}$ \\
\hline $\begin{array}{l}\text { Upper respiratory } \\
\text { affections }\end{array}$ & $\begin{array}{l}\text { Yes } \\
\text { No }\end{array}$ & $\begin{array}{l}219 \\
343\end{array}$ & $\begin{array}{c}168 \\
(29,9) \\
309 \\
(55,0)\end{array}$ & $\begin{array}{c}51 \\
(9,1) \\
34 \\
(6,0)\end{array}$ & $<0,001^{a}$ & $\begin{array}{c}191 \\
(34,0) \\
304 \\
(54,1)\end{array}$ & $\begin{array}{c}28 \\
(5,0) \\
39 \\
(6,9)\end{array}$ & 0,614 & $\begin{array}{c}180 \\
(32,0) \\
321 \\
(57,1)\end{array}$ & $\begin{array}{c}39(7,0) \\
(7,0) \\
22 \\
(3,9)\end{array}$ & $<0,001^{a}$ & $\begin{array}{c}156 \\
(11,2) \\
304 \\
(54,1)\end{array}$ & $\begin{array}{c}63 \\
(27,8) \\
39 \\
(6,9)\end{array}$ & $<0,001^{a}$ \\
\hline Use of medication & Yes & 14 & $\begin{array}{c}10 \\
(1,8)\end{array}$ & $\begin{array}{c}4 \\
(0,7)\end{array}$ & 0,155 & $\begin{array}{c}10 \\
(1,8)\end{array}$ & $\begin{array}{c}4 \\
(0,7)\end{array}$ & 0,052 & $\begin{array}{c}13 \\
(2,3)\end{array}$ & $\begin{array}{c}\text { । } \\
(0,2)\end{array}$ & 0,651 & $\begin{array}{c}11 \\
(2,0)\end{array}$ & $\begin{array}{c}3 \\
(0,5)\end{array}$ & 0,747 \\
\hline & No & 548 & $\begin{array}{c}467 \\
(83,1)\end{array}$ & $\begin{array}{c}81 \\
(14,4)\end{array}$ & & $\begin{array}{c}485 \\
(86,3)\end{array}$ & $\begin{array}{c}63 \\
(11,2)\end{array}$ & & $\begin{array}{c}488 \\
(86,8)\end{array}$ & $\begin{array}{c}60 \\
(10,7)\end{array}$ & & $\begin{array}{c}449 \\
(79,9)\end{array}$ & $\begin{array}{c}99 \\
(17,6)\end{array}$ & \\
\hline Digestive issues & Yes & 25 & $\begin{array}{c}23 \\
(4,1)\end{array}$ & $\begin{array}{c}2 \\
(0,4)\end{array}$ & 0,309 & $\begin{array}{c}17 \\
(3,0)\end{array}$ & $\begin{array}{c}8 \\
(1,4)\end{array}$ & $0,002^{\mathrm{a}}$ & $\begin{array}{c}20 \\
(3,6)\end{array}$ & $\begin{array}{c}5 \\
(0,8)\end{array}$ & 0,133 & $\begin{array}{c}16 \\
(2,8)\end{array}$ & $\begin{array}{c}9 \\
(1,6)\end{array}$ & $0,018^{a}$ \\
\hline & No & 537 & $\begin{array}{c}454 \\
(80,8)\end{array}$ & $\begin{array}{c}83 \\
(14,8)\end{array}$ & & $\begin{array}{l}478( \\
85,1)\end{array}$ & $\begin{array}{c}59 \\
(10,5)\end{array}$ & & $\begin{array}{c}481 \\
(85,6)\end{array}$ & $\begin{array}{c}56 \\
(10,0)\end{array}$ & & $\begin{array}{c}444 \\
(79,0)\end{array}$ & $\begin{array}{c}93 \\
(16,6)\end{array}$ & \\
\hline Pollution & Yes & 20 & $\begin{array}{c}18 \\
(3,2)\end{array}$ & $\begin{array}{c}2 \\
(0,3)\end{array}$ & 0,532 & $\begin{array}{c}18 \\
(3,2)\end{array}$ & $\begin{array}{c}2 \\
(0,3)\end{array}$ & 0,806 & $\begin{array}{c}15 \\
(2,6)\end{array}$ & $\begin{array}{c}5 \\
(0,9)\end{array}$ & $0,035^{a}$ & $\begin{array}{c}17 \\
(3,0)\end{array}$ & $\begin{array}{c}3 \\
(0,5)\end{array}$ & 0,734 \\
\hline & No & 551 & $\begin{array}{c}468 \\
(82,0)\end{array}$ & $\begin{array}{c}83 \\
(14,5)\end{array}$ & & $\begin{array}{c}486 \\
(85,1)\end{array}$ & $\begin{array}{c}65 \\
(11,4)\end{array}$ & & $\begin{array}{c}495 \\
(86,7)\end{array}$ & $\begin{array}{c}56 \\
(9,8)\end{array}$ & & $\begin{array}{c}452 \\
(79,2)\end{array}$ & $\begin{array}{c}99 \\
(17,3)\end{array}$ & \\
\hline
\end{tabular}

Legend: ${ }^{\mathrm{a}} \mathrm{p}<0,050(5 \%)$

0.044), upper respiratory affections ( $p<0.001)$, and pollution ( $\mathrm{p}=0.035)$. There was no association between sore throat and stress $(p=0.092)$, smoking $(p=0.073)$, use of medication $(\mathrm{p}=0.651)$, and digestive issues $(\mathrm{p}=$ 0.133).

The statistical analysis results of the association between the presence of phlegm and its possible causes revealed that there was a significant association between presence of phlegm and smoking ( $p<0.001)$, upper respiratory affections $(\mathrm{p}<0.001)$, and digestive issues $(\mathrm{p}=0.018)$. There was no association with intense vocal use $(p=0.700)$, stress $(p=0.148)$, use of medication $(\mathrm{p}=0.747)$, and pollution $(\mathrm{p}=0.734)$

\section{DISCUSSION}

The questionnaire was the instrument of choice for data collection in this study as it has also been used in most studies with the same fundamental characteristics $(9,10)$ and had the advantage of meeting the research aim in a rapid and brief manner.

With regard to the general health aspects, it is interesting to note that even though most students considered their health satisfactory, part of the sample population was undergoing medical treatment and/or using some type of medication. Furthermore, the fact that 
the number of subjects taking some type of medication leads to the hypothesis that these subjects were taking more than one medicine, or self-medicating.

Smoking, a habit also found among radio students and professionals (11), and in smaller numbers in a study concerning risk behaviors to the health of adolescents (12), is another factor that must be focused on and that represents preoccupying results, since the studied population was composed of young adults who would be expected to be in excellent health with low indexes of medical treatments and use of medication, and without deleterious health habits.

As far as the vocal aspects went, more than half the subjects reported having at least one vocal symptom during the month the data were collected. In a study conducted with teachers, almost one-third of participants had an indication of voice disorder, as they reported two or more vocal symptoms (1).

Upon the execution of the association analysis, it was possible to observe the relationship between vocal symptoms of hoarseness, vocal fatigue, sore throat, and phlegm and the causes that may account for these symptoms, as reported by the subjects.

The percentage of individuals that reported hoarseness was similar to that found in another study with college students (4). Other studies $(13,14)$ have reported lower values than those obtained in the present investigation, perhaps because the first study was conducted with a population from another country and who had laryngeal disorders, and the second approached the symptoms using frequency indicators ("often", "sometimes", "never"). Another study reported a higher percentage than that in this research, possibly because they dealt with a population that could have had laryngeal disorders, as it comprised individuals who sought assistance during the 1999 National Voice Week Campaign (5). Similarly, higher values were also found for reported hoarseness among individuals who took part in an event directed towards vocal health protection (15). Another study with a higher hoarseness percentage had been conducted with a population of industrial workers (16), and the findings are possibly due to the fact that the participants were subject to environmental work risks that are deleterious to the voice, such as heat and dust.

The association analysis made it possible to state that intense vocal use and upper respiratory affections, according to the interviewed subjects, influences the presence of hoarseness.

The relationship between hoarseness and upper respiratory affections includes changes in resonance and vocal projection, as there is an alteration in facial cavities. This generates laryngeal strain as a compensation mechanism, which characterizes inadequate vocal use. For some authors, vocal abuse was the main cause of hoarseness (7).

The presence of vocal fatigue is associated to intense vocal use (3). When studying a group of teachers, the authors affirmed that intense vocal use was the main cause of vocal fatigue, in addition to stress and digestive issues (17). Vocal fatigue and the digestive problems mentioned by the college students in this investigation, therefore, are responses to the initial state of stress in this population, which may have been more evident as the data were collected towards the end of the academic semester (November).

As with vocal fatigue, sore throat was present in subjects with vocal symptoms. The obtained data were similar to the findings of a study with workers (16), and the percentage of reported sore throat was lower than that in a study with a general population of park goers (14).

Regarding the association with the possible causes reported by the students, the presence of sore throat was influenced by intense vocal use, upper respiratory affections, and pollution. These findings are in accordance with those from studies that presented a relationship between throat symptoms (sore throat being one of them) and intense vocal use (18). The upper respiratory affections may be related to the presence of acute laryngitis, or caused by dryness of the vocal tract due to oral breathing, which may cause a sensation of a sore throat (19). In addition to upper airway affections, pollution also harms the body due to the presence of carbon monoxide and other pollutants, increasing the incidence of upper airway infections, cough, and throat irritation, among other effects (20). Thus, these factors may directly affect the vocal tract.

The percentage of students who reported having phlegm was close to the value found in another study (14). Perhaps because subjects with different characteristics from those in this study were analyzed, other authors reported lower values for the presence of phlegm than that in the present study (16).

In the association analysis between the presence of phlegm and its reported causes, this symptom is associated to smoking, upper respiratory affections, and digestive issues. Smoking is a deleterious habit to the voice because the smoke from a tobacco cigarette acts on the mucosa that lines the vocal tract and the vocal cords themselves. Therefore, there is an increase in mucus secretion in order to protect this region(21). The secretion, 
generated by allergic rhinitis, chronic or acute sinus infections, or by gastroesophageal reflux, favors the habit of throat clearing, which is one of the most commonly reported symptoms by individuals who have these affections (22).

Among the references mentioned in the present study, most, in at least one of the vocal symptoms, reported different results (for more or for less) from that of the present study. Therefore, as a sequel to this investigation, it would be interesting to analyze in detail the vocal symptoms reported by the subjects; in other words, observe if there is a direct manifestation of the disorder or a sign that would confirm the reported symptom through a vocal assessment by an otorhinolaryngologist and an SLP in order to confront and confirm the findings of this study.

A suggestion is that more studies in the field of voice be designed with a similar theme to the present study. This way, it will be possible to establish reference values for voice disorders and consequently subsidize future measures for collective health, as well as to demonstrate the importance of the presence of SLPs in teams that plan collective health measures, for example, those related to smoking, the environment, and habits.

\section{CONCLUSIONS}

This study showed that intense vocal use, stress, digestive issues, pollution, upper respiratory affections, and smoking are associated to vocal symptoms reported by college students.

Therefore, it was confirmed that not only do health aspects and those directly related to the voice interfere with its production, but also in the opinion of the studied population, the external environment and habits interfere significantly in the appearance of vocal symptoms.

\section{REFERENCES}

1. Pordeus AMJ, Palmeira CT. Inquérito de prevalência de problemas da VOZ em professores da Universidade de Fortaleza. Pró-Fono, 1996; 8(2):15-24.

2. Sliwinska-Kowalska M, Niebudek-Bogusz E, Fiszer M, Los-Spychalska T, Kotylo P, Sznurowska-Przygocka B, Modrzewska $M$. The prevalence and risk factors of occupational voice disorders in teachers. Folia Phoniatr Logop, 2006; 58(2):85-101.

3. Chang A, Karnell MP. Perceived phonatory effort and phonation threshold pressure across a prolonged voice loading task: a study of vocal fatigue. J Voice, 2004; 18(4):454-466

4. Simberg S, Laine A, Sala E, Ronnemaa AM. Prevalence of voice disorders among future teachers. JVoice, 2000; 14:231235 .

5. Ferreira LB, Ferreira DS. Estudo descritivo de 451 atendimentos na campanha da semana nacional de voz. [periódico on line] Rev Bras Otorriolaringol, 2001; 67[05 telas]. Disponível em http://www.sborl.org.br/acervo/ rev67-1_estudo451atendimentos.asp [citado 2005 abril 16].

6. Araujo AS, Moura JR, Camargo LA. Principais sintomas otorrinolaringológicos em escolares. Rev Arq Internac ORL, 2004; 8(1) Disponível em http://www.arquivosdeorl.org.br/ conteudo/acervo_port.asp?id=262 [citado 2010 junho 28] .

7. Behlau M, Madazio G, Feijó D, Pontes P. Avaliação da vOz. In: Behlau M. Voz-o livro do especialista. Riode Janeiro: Revinter, 2001:60-3.

8. Ferreira LP, Giannini SPP, Latorre MRDO, Zenari MS. Distúrbio de voz relacionado ao trabalho: proposta de um instrumento paravaliação de professores. Rev Dist Comun, 2007; 19(1):127-136.

9. Mourão LF, Trevizor TT, Granato C, Fedosse E, Silvério KCA. Comparação do uso vocal de feirantes das cidades de Piracicaba e São Paulo. Rev Dist Comun, 2003; 15(1):3958.

10. Ferreira LP, Benedetti PH. Condições de produção vocal de professores de deficientes auditivos. Rev CEFAC, 2007; 9(1):79-89.

11. Timmermans B, De Bodt M, Wuyts F, Van de Heyning $\mathrm{P}$. Vocal hygiene in radio students and in radio professionals. Logopedics Phoniatrics Vocology, 2003; 28(3):127-132.

12. Farias Júnior JC, Nahas MV, Barros MVG, Loch MR, Oliveira ESA, De Bem MFL, Lopes AS. Comportamentos de risco à saúde emadolescentes no Sul do Brasil: prevalência e fatores associados. Rev Panam Salud Publica, 2009; 25(4):344-52.

13. Coyle SM, Weinrich BD, Stemple JC. Shifts in relative prevalence of laryngeal pathology in a treatment-seeking population. J Voice, 2003; 15:424-440.

14. Oliveira RH. Queixas vocais e sua relação com questões de saúde e do meio ambiente em frequentadores de parque público de São Paulo. 2004. Dissertação (Mestrado) Pontifícia Universidade Católica de São Paulo, São Paulo.

15. Köhle J, Nemr K, Leite GCA, Santos AO, LehnCN, Chedid 
HM. Ação de proteção de saúde vocal: perfil da população e correlação entre auto-avaliação vocal, queixas e avaliação fonoaudiológica perceptivo-auditiva e acústica. Rev Dist Comun, 2004; 16(3):333-341.

16. Arakaki FN, Ferreira LP, Troni CR, Lima FS. Condições de produção vocal de trabalhadores industriais: levantamento de dados na presença de riscos ocupacionais. Fono Atual, 2006; 36:44-55.

17. Fabron EMG, Omote S. Queixas vocais entre professores e outros profissionais. In: Ferreira LP, Costa HO. Voz ativa - falando sobre o profissional da voz. São Paulo: Rocca, 2000 p. 91-102.

18. Vintturi J, Alku P, Sala E, Sihvo M, Vilkman E. Loadingrelated subjective symptoms during a vocal loading test with special reference to gender and some ergonomic factors. Folia Phoniatrc Logop, 2003; 55(2):55-69.
19. Tavares JG, Silva EHAA. Considerações teóricas sobre a relação entre respiração oral e disfonia. Rev. Soc. Bras. Fonoaudiol, 2008; 13(4):405-410.

20. Cançado, JED et al. Repercussões clínicas da exposição à poluição atmosférica. J. Bras. Pneumol [online], 2006; 32 suppl 2: S5 - S11.

21. Duarte JL, Faria FA, Ceolin DS, Cestari TM, Assis GF. Effects of passive smoke inhalation on the vocal cords of rats. Rev Bras Otorrinolaringol (Engl Ed), 2006; 72(2):210216.

22. Karkos PD, Benton J, Leong SC, Karkanevatos A, Badran $\mathrm{K}$, Srinivasan VR, Temple RH, Issing WJ. Trends in laryngopharyngeal reflux: a British ENT survey. Eur Arch Otorhinolaryngol, 2007; 264(5):513-517. 